\title{
Spain: Financial Sector Assessment Program-Technical Note- Regulation, Supervision, and Governance of the Spanish Cajas
}

This Technical Note on Financial Sector Assessment Program on Regulation, Supervision, and Governance of the Spanish Cajas for Spain was prepared by a staff team of the International Monetary Fund as background documentation to the Financial Sector Assessment Program with the member country. It is based on the information available at the time it was completed in May 2006. The views expressed in this document are those of the staff team and do not necessarily reflect the views of the government of Spain or the Executive Board of the IMF.

The policy of publication of staff reports and other documents by the IMF allows for the deletion of market-sensitive information.

To assist the IMF in evaluating the publication policy, reader comments are invited and may be sent by e-mail to publicationpolicy@imf.org.

Copies of this report are available to the public from

International Monetary Fund • Publication Services

700 19th Street, N.W. • Washington, D.C. 20431

Telephone: (202) 6237430 • Telefax: (202) 6237201

E-mail: publications@imf.org • Internet: http://www.imf.org

Price: $\$ 15.00$ a copy

\section{International Monetary Fund Washington, D.C.}



FInANCIAL SECTOR ASSESSMENT PROGRAM SPAIN

\section{TeChNiCAl Note on Regulation, SUPERVISION, AND GOVERNANCE OF THE SPANISH CAJAS \\ MAY 2006}


Contents

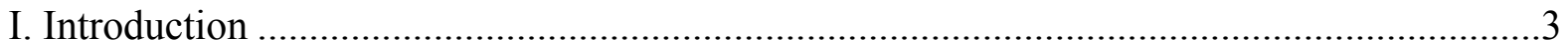

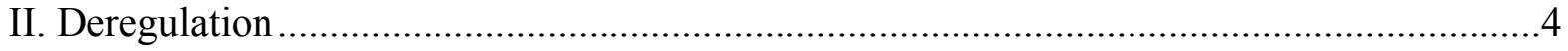

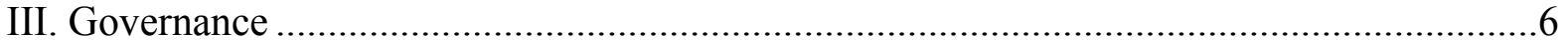

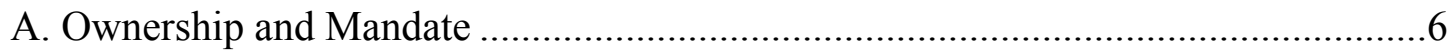

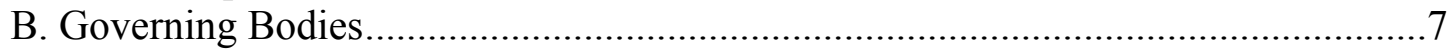

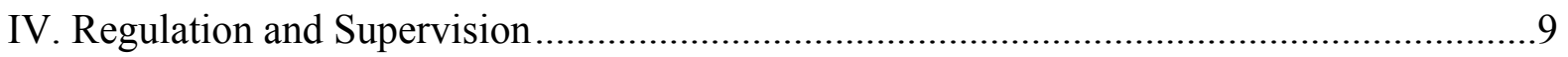

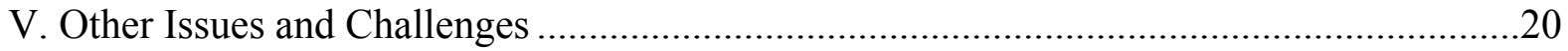

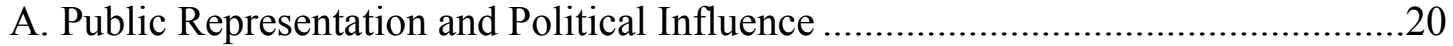

B. Barriers that Prevent the Strengthening of Competition ......................................22

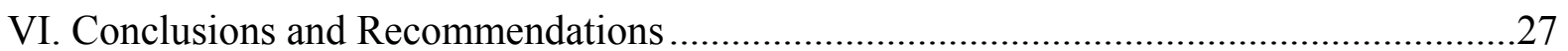

Tables

1. Division of Oversight Responsibilities: Cajas Structure and Organization ......................12

2. Division of Oversight Responsibilities: Cajas Activities .............................................13

3. Regulatory and Supervisory Powers of Autonomous Communities over Cajas ................14

4. Number of Cajas per Autonomous Region ............................................................20

5. Executive Turnover in Banks and Cajas, 1986-2000 ....................................................22

Figures

1. Banking System: Evolution of Market Shares, 1976-2003 ...........................................5

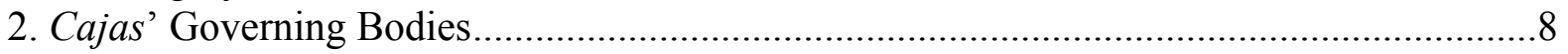

Boxes

1. Capital Instruments Available to Spanish Savings Banks ............................................24

2. Savings Banks and Capital Instruments in Norway ..................................................25 


\section{Regulation, Supervision, AND GovernanCe OF THE SPANiSh $C_{A J A} \boldsymbol{S}^{1}$}

\section{INTRODUCTION}

1. Spain's financial markets have been deregulated since 1977, spurred by political change and closer ties with the European Communities. As part of this process, Spain's cajas de ahorros (savings banks) were gradually reformed so that they could compete in the newly liberalized market. In particular, they were allowed to engage in universal banking activities previously reserved to (commercial) banking institutions, and, since 1988, to expand into all regions of Spain and abroad. The cajas have been very successful in taking advantage of deregulation by expanding significantly in the lending and deposit-taking markets, where they have now a market share close to or above that of banks.

2. In parallel with deregulation, the governance structure of the cajas was reformed. Since 1977, their governing bodies were opened to a broader representation-including depositors, founders, employees, and other cultural, charitable, and academic organizationswith a view to reducing what had been substantial political influence, and thus allowing them to compete more effectively with banks.

3. Despite the broader representation in cajas' governing bodies and the liberalization measures aimed at leveling the playing field of cajas and banks, the governance structure of cajas is more extensively regulated — by the State and by the Autonomous Communitiesthan that of banks. Furthermore, the governance framework of cajas has been frequently revised in the period 1977-2005. Legislative reforms - in 1985 and 2002 - and rulings of the Constitutional Tribunal introduced changes in the governance structure of cajas. Reforms introduced in 1985, and rulings of the Constitutional Tribunal in 1988 increased public sector representation, whereas the legislation enacted in 2002 reduced it. Despite these institutional changes, the fundamental character of the cajas as credit institutions that are also private organizations with foundational origins and social objectives has remained intact. ${ }^{2}$ Moreover, an issue that has frequently arisen in Spain's public debate is whether and to what extent various levels of government and political parties have influenced business decisions made by cajas.

4. Against this background, a fundamental policy question affecting the Spanish cajas is whether the existing governance structure is conducive to sound risk management by ensuring that these institutions' business decisions are free of political interference and that proper internal controls are in place. A supplementary question is whether deregulation has sufficiently leveled the playing field between commercial and savings banks to support competition. This latter question brings to the front the dual character of the regulation and supervision of credit institutions in Spain: commercial banks are regulated and supervised by the central government, whereas savings banks are regulated and supervised both by the

\footnotetext{
${ }^{1}$ Prepared by Mario Catalán and Marina Moretti.

${ }^{2}$ For more details about the legal and institutional nature of cajas, see Section III.A.
} 
central government and by Autonomous Communities. Although the powers of Autonomous Communities over savings banks are restricted to aspects of internal organization and conduct of business, the division of oversight responsibilities over savings banks raises issues such as the need for coordination, in particular to avoid the possibility of conflicts.

5. This note discusses these issues and is structured as follows. Section II provides background on the financial liberalization and deregulation process that started in 1977, with special reference to the cajas. Section III provides an overview of the cajas' governance structure. Section IV analyzes the regulation and supervision of cajas, with particular reference to the division of responsibilities between the central government (State) and the Autonomous Communities. Section V discusses the main challenges going forward in terms of ensuring the cajas' operational autonomy and further leveling the playing field between savings and commercial banks. Section VI summarizes the main findings and provides recommendations.

\section{Deregulation}

6. The deregulation of Spanish financial markets since 1977 had a profound effect on the cajas.

7. The evolution of cajas has taken place in three stages. In the first stage, starting in 1835, the role of cajas was the promotion of savings. Most cajas were created in the first half of the nineteenth century by local councils, associations, and religious orders, or evolved from the existing pawnshops (montes de piedad). Their original function was to collect savings from the local communities, provide small loans backed by pawns-goods held in pledge as security for the loan - and channel their "profits" (excedentes) back to these communities through social and cultural projects.

8. In the second stage, starting in 1926, the cajas' business shifts toward granting credit to the public sector and other sectors favored by the government. Until the 1970s, the cajas were subject to extensive government regulation including directed credit (the so-called coeficientes de inversión obligatoria), ${ }^{3}$ a prohibition to engage in business with companies, and the right of the finance minister to veto high level appointments to the cajas.

9. In the third stage, starting in 1977, the role of cajas shifts toward the promotion of credit to households and small and medium enterprises, and also — in the last decade - toward industrial shareholdings, while their regional specificity declines. As part of the deregulation process, the cajas were allowed to carry out universal banking activities starting in 1977, and directed credits were gradually eliminated (although not fully abolished until 1992). Further deregulation in 1988 allowed the cajas to expand their operations outside their home regions, allowing them to compete on a national (and potentially international) scale. Legal barriers

\footnotetext{
${ }^{3}$ The coeficientes de inversión obligatoria required financial institutions (both banks and cajas) to invest 50 percent of their deposits in government paper, and another 30 percent in lending for set purposes (largely housing in the case of cajas).
} 
preventing mergers and strategic alliances among cajas were eased in 2002, allowing cajas from different regions to merge. ${ }^{4}$

10. The outcomes of this liberalization were rapid expansion and consolidation. The cajas have consistently gained market share over the past 30 years, in a few cases accelerated by the acquisition of banks. Cajas' share in total banking system assets grew from 22 percent in 1976 to 33 percent in 2004; their share in lending from 18 to 45 percent; and their share in deposits from 33 to 52 percent - in the latter case surpassing banks by a significant margin (Figure 1). Most cajas now have branches outside their home regions and some of them have established truly national networks - in particular the Caja de Ahorros y Pensiones de Barcelona (La Caixa) and the Caja de Ahorros y Monte de Piedad de Madrid (Caja Madrid).

11. The liberalization and the intensification of competition in the Spanish banking system spurred a process of consolidation that affected both commercial and savings banks. In the case of cajas, a significant number of mergers took place over the past 30 years, bringing their total number from 84 in 1976 to 46 in 2004. While no caja has ever defaulted on its obligations, in a few cases mergers resulted from the need to resolve a problem caja. The latest case occurred in 2001, when the Caja de Ahorros de Valencia, Castellón y Alicante (Bancaja), the third largest Spanish caja by assets, absorbed the Caja de Ahorros $y$ Préstamos de Carlet, a small savings bank based in Valencia that had encountered financial difficulties. ${ }^{5}$

Figure 1. Banking System: Evolution of Market Shares, 1976-2003
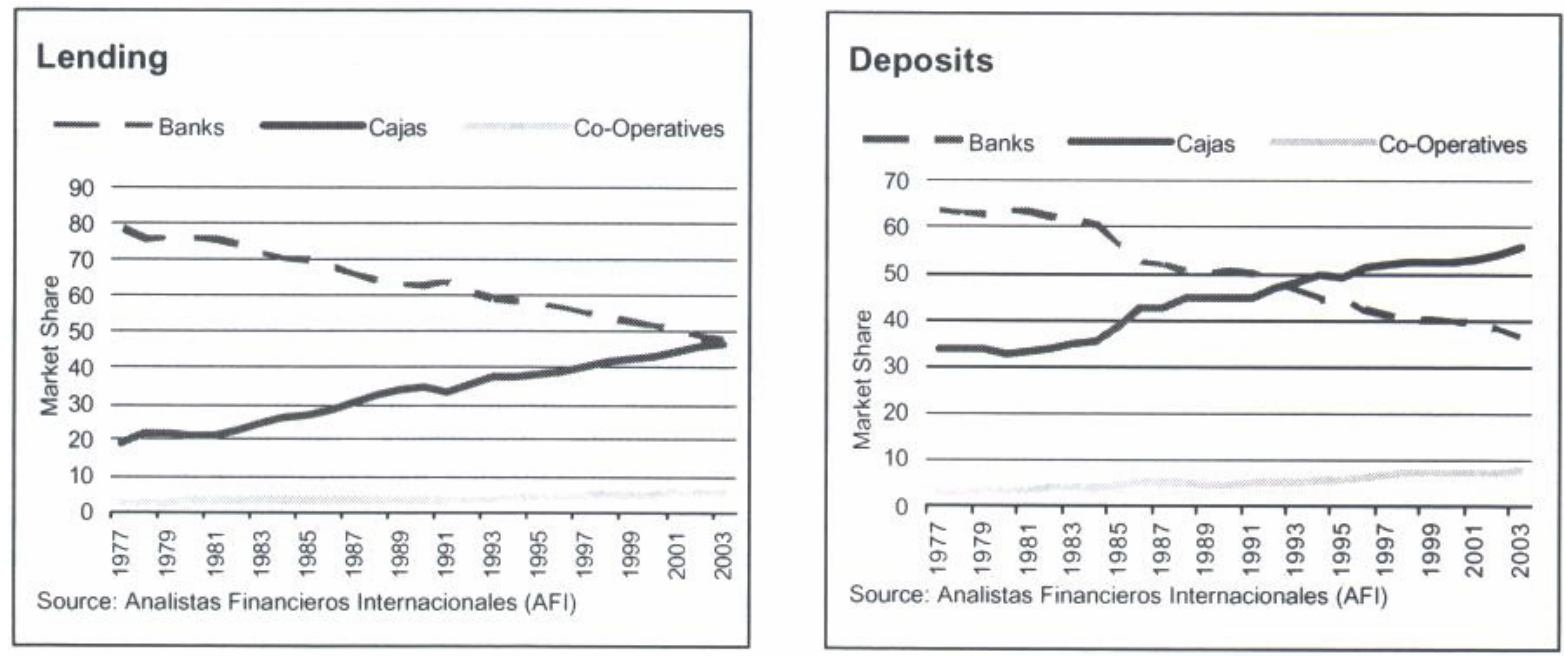

\footnotetext{
${ }^{4}$ Previously, only mergers between cajas from the same region were regulated.

${ }^{5}$ FitchRatings, 2004, The Spanish Cajas: A Consolidated Force in Spanish Banking, Special Report, April.
} 


\section{GoVERnANCE}

\section{A. Ownership and Mandate}

12. In Spain, current legal interpretation is that cajas are credit institutions that act and are organized as private enterprises but have foundational origins and fulfill social functions. Their ownership structure is such that those exercising control- the public sector, depositors, employees, and others that are represented in the governing bodies - are not legal owners. The cajas do not have any share capital and equity consists mainly of reserves generated through retained earnings. Their social involvement and public sector representation created ambiguity as to whether they belong to the private or the public sector, but the Constitutional Tribunal clarified their nature. ${ }^{6}$

13. Cajas are required to allocate at least half of their profits to reserves, and they channel the remainder back into the community toward projects that fall under their social mandate (obra social). ${ }^{7}$ Cajas seek to maximize their profits - and thus, their allocation to the obra social - through their day-to-day business operations and compete fiercely with banks and other credit institutions for the provision of financial intermediation services. A key feature of cajas is that they pursue, both through their activities and the allocation of their profits, the following main objectives: ${ }^{8}$

- $\quad$ universal provision of financial services (promote savings among low- and middleincome classes);

- $\quad$ economic efficiency (guarantee safety and profitability);

- $\quad$ promotion of competition and avoidance of monopolistic practices (avoid usury);

- $\quad$ contribution to welfare and redistribution (provide benefits for the poor); and

- $\quad$ promotion of regional and community development.

14. The share of profits allocated to the obra social - averaging close to 30 percent per year-has decreased somewhat over the past decade, albeit the absolute level of profits has increased. The decline in the share of obra social is accounted for by increased taxation-

\footnotetext{
${ }^{6}$ In a 1988 ruling, the Tribunal noted that they are credit institutions with a social character that do not distribute profits to private parties (entidades sin fin de lucro or non-profit institutions), which does not correspond to the traditional concept of enterprise. See Constitutional Tribunal, ruling 49/1988 of March 22, 1988.

${ }^{7}$ This requirement, initially set by national legislation (Real Decree-August 27, 1977), has to be respected by all the Autonomous Communities.

${ }^{8}$ Historical missions are in parentheses.
} 
cajas were (almost) tax-exempt before 1985 - and higher capitalization requirements imposed on credit institutions. The obra social share has also been increasingly allocated to the provision of public goods - particularly cultural, environmental, and research — which may suggest that its more direct re-distributional role has been declining.

15. The obra social has typically been focused on low-income groups, the elderly, and less populated areas. A recent study shows that the obra social benefits 96 percent of the Spanish population, with the disadvantaged groups receiving most of the benefits. ${ }^{9}$ Spanish citizens, on average, make use of services or public goods provided by savings banks about three times per year. The study concludes that the extensive provision of social and cultural services by the private sector - strictly, by savings banks - in Spain cannot be found in any other country. Finally, it suggests that the private provision of public goods through the obra social complements well the government's provision of such goods. Specifically, savings banks play a leading role in identifying specific needs of disadvantaged groups, and once these needs have been identified, the public sector plays its own role. In this context, the savings banks have also helped to improve the overall provision of public goods. Moreover, as Spain's per capita income has increased, obras sociales have been adjusting the menu of those goods.

\section{B. Governing Bodies}

16. The early reforms in the cajas' governance, launched in parallel with liberalization in 1977, aimed at standardizing their internal structure so as to avoid the moral hazard of selfperpetuating boards of directors (and their capture by executive managers) as well as to reduce the state's influence in the running of these institutions. In particular, management responsibility was transferred to cajas' founders (including, in some cases, the local governments and/or Autonomous Communities), ${ }^{10}$ depositors, employees, and other groups (local academic, cultural, and charitable organizations). National standards of internal organization were introduced by legislation (Figure 2); these standards can be modified by the Autonomous Communities with a view to adapting the general rules to the conditions in their respective region. ${ }^{11}$

- $\quad$ General assembly. The general assembly_-similar to the shareholders' meeting of a public limited company - is the main governing body of a caja, responsible for providing its strategic orientation and selecting management. The LORCA (Law $31 / 1985$ of August 2, 1985) set the number of members, which can vary between 60

\footnotetext{
${ }^{9}$ See PricewaterhouseCoopers, 2005, Valoración del impacto de la obra social. The study was sponsored by the confederation of Spanish savings banks (CECA).

10 The 1978 Constitution granted Spain's regions a certain degree of autonomy, embodied in a new level of public administration, the Comunidades Autónomas (Autonomous Communities).

${ }^{11}$ Deviations from the national norm are permissible with respect to the number of assembly members and each group's share; the inclusion of representatives from other groups; and rules for selecting assembly members.
} 
and 160 depending on the size of the caja. ${ }^{12}$ The Ley Financiera (Law 44/2002 of November 22, 2002) capped the number of public sector representatives-State, Autonomous Communities, public law agencies and Municipalities - at 50 percent of members of the general assembly. ${ }^{13}$ A 2003 amendment to the LORCA also altered public sector representation in the assembly by requiring that all the Municipalities in which the caja has branches be represented.

- $\quad$ Board of directors. Board members are selected by the assembly usually from its ranks and reflect its representation. ${ }^{14}$ Besides management, the board is responsible for the cajas' social mandate. The board's chairman is also president of the assembly and of the caja.

- Internal audit function. Members of the audit committee are also selected by the assembly from its ranks and reflect its representation.

Figure 2. Cajas' Governing Bodies

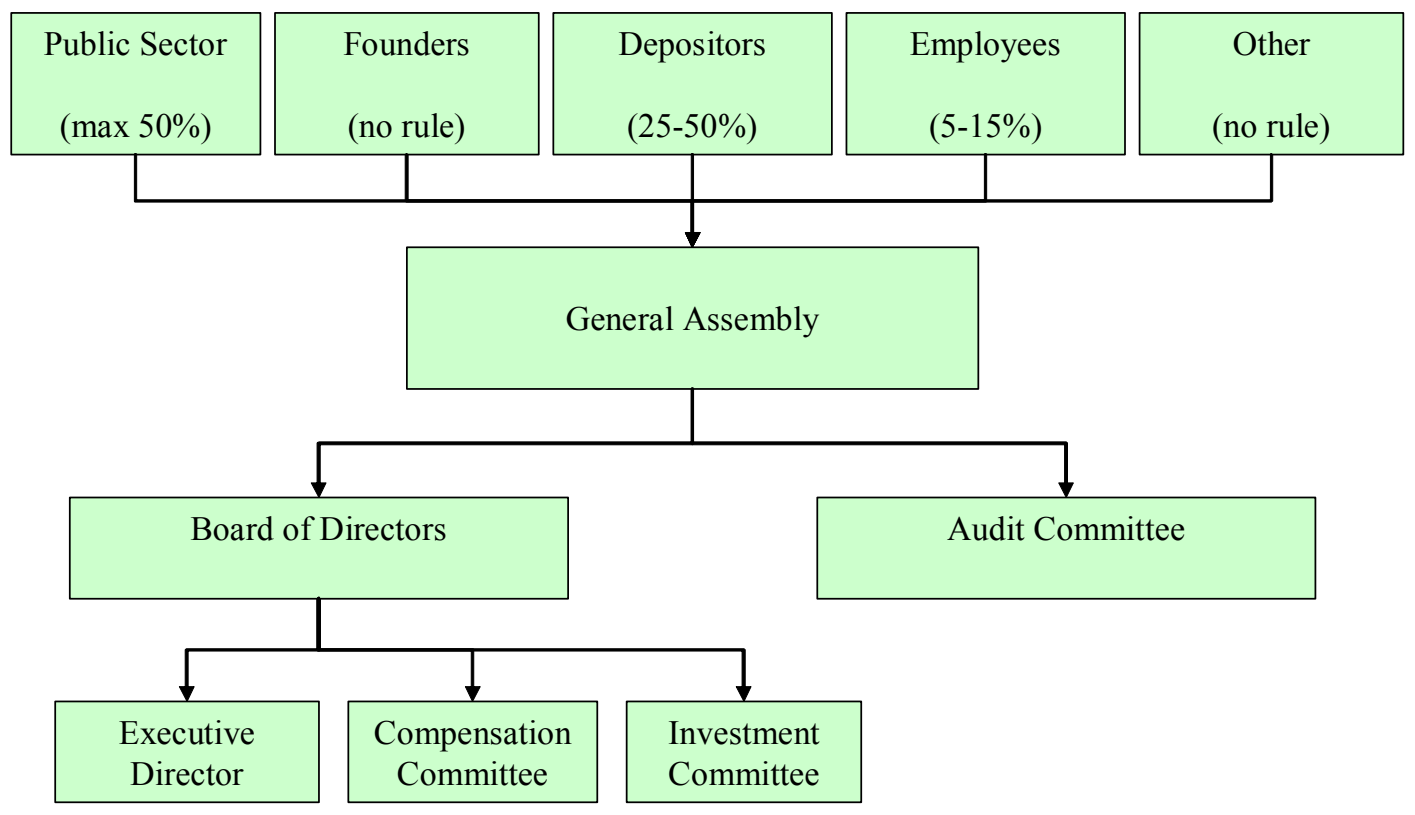

\footnotetext{
${ }^{12}$ The LORCA (Ley sobre Órganos Rectores de las Cajas de Ahorros) also reinforced the influence of the public sector in cajas' decision-making.

${ }^{13}$ This reform was partly in response to the need to clarify whether cajas are public or private undertakings under EU law. EU directives define public undertakings as "any undertaking over which the public authorities may exercise directly or indirectly a dominant influence by virtue of their ownership of it, their financial participation therein, or the rules which govern it" (Directive 80/723-EEC of June 25, 1980).

${ }^{14}$ Board members are usually selected among assembly members. However, up to two board members may be selected each from the ranks of depositors and public sector, without being members of the assembly.
} 
- Management. Most board functions are delegated to the executive director level (executive committee and director general). The executive director(s) are appointed by the board based on professional criteria and confirmed by the assembly. They are expected to serve terms of between four and six years (depending on each caja's by-laws) and although re-election is allowed, they cannot serve for longer than 12 years.

- $\quad$ Other. The 2003 Law on Transparency and Governance (Law 26/2003 of July 17, 2003) added new governing bodies to the cajas - specifically, a compensation committee that provides information on the compensation and incentives policies of board members and senior managers; and an investment committee responsible for proposing investment strategy and monitoring compatibility between the caja's investment portfolio and its social mandate. ${ }^{15}$

\section{REgULATION AND SUPERVISION}

17. Unlike banks, the cajas are regulated and supervised by the central governmentthrough the ministry of the economy and the central bank-as well as by the Autonomous Communities (ACs). ${ }^{16}$ The division of regulatory and supervisory powers between the central government and the ACs is determined by the Constitution, the ACs' own Statutes (Estatutos de Autonomía) — which differ across ACs - and the rulings of the Constitutional Tribunal.

18. Spain's Constitution contains no explicit references to savings banks - albeit it does refer explicitly to "credit and banking" in its Articles 148 and 149. This fact, combined with the special legal nature of cajas - credit institutions and not-for-profit private foundationsgenerated some conflicts regarding the division of regulatory and supervisory responsibilities between the State (central government) and the ACs, which the Constitutional Tribunal had to settle.

19. The guiding Constitutional principle regarding the division of powers is that the State has rights and responsibilities to set "the bases that shall order credit, banking and insurance activities in Spain"-las bases para la ordenación del crédito, banca y seguros (Article 149 of the Constitution). These rights and responsibilities apply to savings banks, as they are legally considered credit institutions.

\footnotetext{
${ }^{15}$ The distribution of seats in the two commissions must be in line with the board's (and therefore the assembly's) voting structure.

${ }^{16}$ An exception are the three savings banks linked to the Catholic Church-CajaSur (Andalucía), Cajacírculo (Castilla y León), and Caja Inmaculada (Aragón) — which are supervised by the central government instead of the Autonomous Community (see Table 1 below). A five-year conflict in Spanish tribunals over the division of oversight responsibilities and the control of CajaSur - involving the savings bank, the central government, the Junta de Andalucía and the representatives of the Church in the caja - has been resolved recently. The agreement between the Church and the Junta de Andalucía restored the oversight powers of the Autonomous Community in exchange for a rebalancing of representation powers within the savings bank. See, for instance, CincoDias, October 17, 2005, "La rápida reconversión de CajaSur."
} 
20. The "bases" shall define a minimum common ground to ensure the unity of the system. The spirit of the Constitution is that preserving the unity of the system requires all financial institutions in Spain - regardless of their regional origins in the case of cajas - to be subject to the same "bases."

21. This constitutional principle gives rise to the following practical questions: what is the exact definition of the "bases"?; what is the meaning of "bases" regarding regulatory and supervisory practices?. Over the years, rulings of the Constitutional Tribunal (CT) have clarified the meaning and extent of the "bases."

- $\quad$ First, the CT has confirmed that not only the State, but also the ACs have regulatory and supervisory powers over cajas. The CT's ruling 48/1988-Sentencia del Tribunal Constitucional (STC) 48/1988 - granted regulatory and supervisory powers over saving banks to ACs on the grounds of the cajas' regional specificity and importance. ${ }^{17}$ The State and the ACs have regulatory, supervisory and sanctioning powers within their corresponding areas of responsibilities.

- Second, a direct implication of granting powers to ACs is that "the bases" cannot aim at complete uniformity, that is, they cannot be so detailed that they prevent ACs from exercising any regulatory and supervisory rights.

- Third, the "bases" must be stable to the greatest possible extent. The State has, however, the right to modify the "bases", and if it does so, the ACs must adapt their own norms accordingly. It is desirable that the State defines the "bases" through laws, but it can also define them through lower-level legal instruments such as circulars and simple executive actions — associated with competencias ejecutivas.

- $\quad$ Fourth, regulations and executive actions aimed at safeguarding the solvency of credit institutions are considered "basic" by the Constitutional Tribunal. These include: the definition of own funds, capital adequacy requirements, requirements on consolidation of accounting balances and results, limits on credit risk concentration and industrial participations, regulations on exchange and market risk exposure, informational and transparency requirements. ${ }^{18}$

\footnotetext{
${ }^{17}$ Notice that currently banks are not characterized by such regional specificity and importance. Even though the traditional territorial limits of cajas were eliminated in the 1980s, and thus, their regional specificity declined, it remains significant. The $\mathrm{CT}$ also ruled on territorial issues and divisions of responsibilities among ACs; the following case can be cited as an example: a clause in Law 31/1985 stated that the central government would hold full oversight responsibilities over saving banks that raise more than 50 percent of their deposits outside their region of origin. The CT ruled that such clause was unconstitutional. Also, the CT rulings allowed for the possibility that the State could enact "basic" legislation to frame the relations among ACs regarding their relative powers, with the aim of safeguarding the general interest and encouraging solidarity among ACs. This legislation has not materialized yet.

${ }^{18}$ The corresponding rulings of the Constitutional Tribunal are the following: STC 96/1996, 135/1992, 37/1997, 235/1999.
} 
- $\quad$ Fifth, the responsibilities that fall within the orbit of ACs powers generally have to do with safeguarding social objectives, transparency and consumer protection.

22. Tables 1 and 2 show the current division of regulatory and supervisory powers between the State and the ACs classified according to(a) powers affecting the internal structure and organization of saving banks, and (b) powers affecting the activities of savings banks.

23. Although the objective of defining the "bases" is to preserve the unity of the Spanish financial system, the actual definitions of such "bases" that result from rulings of the Constitutional Tribunal may appear, in some particular cases, not fully consistent with that objective. Of particular concern in this regard are the ACs powers to grant large investment and credit authorizations and to veto merger and acquisition proposals made by savings banks even if supported by the Bank of Spain.

24. The first of these powers (over investment and credit authorizations) can affect solvency. Although ACs are not currently imposing investment and credit authorization requirements - and it is commonly understood that they will not do so - the fact that the legislation explicitly allows them to do so creates ambiguities.

25. The second power (over mergers) can impede further consolidation of the financial system as it may prevent economically optimal mergers. The fact that mergers and acquisitions among cajas are subject to approval by the regional authority (of both ACs in case of mergers or acquisitions across community borders) puts a hurdle to the efficiency of mergers and may open the door for political interference. So far, all but one of the mergers involving cajas have been between institutions from the same region. ${ }^{19}$

\footnotetext{
${ }^{19}$ The only merger between cajas from different regions was between Caja Madrid and Caja de Ceuta.
} 


\section{Table 1. Division of Oversight Responsibilities: Cajas Structure and Organization}

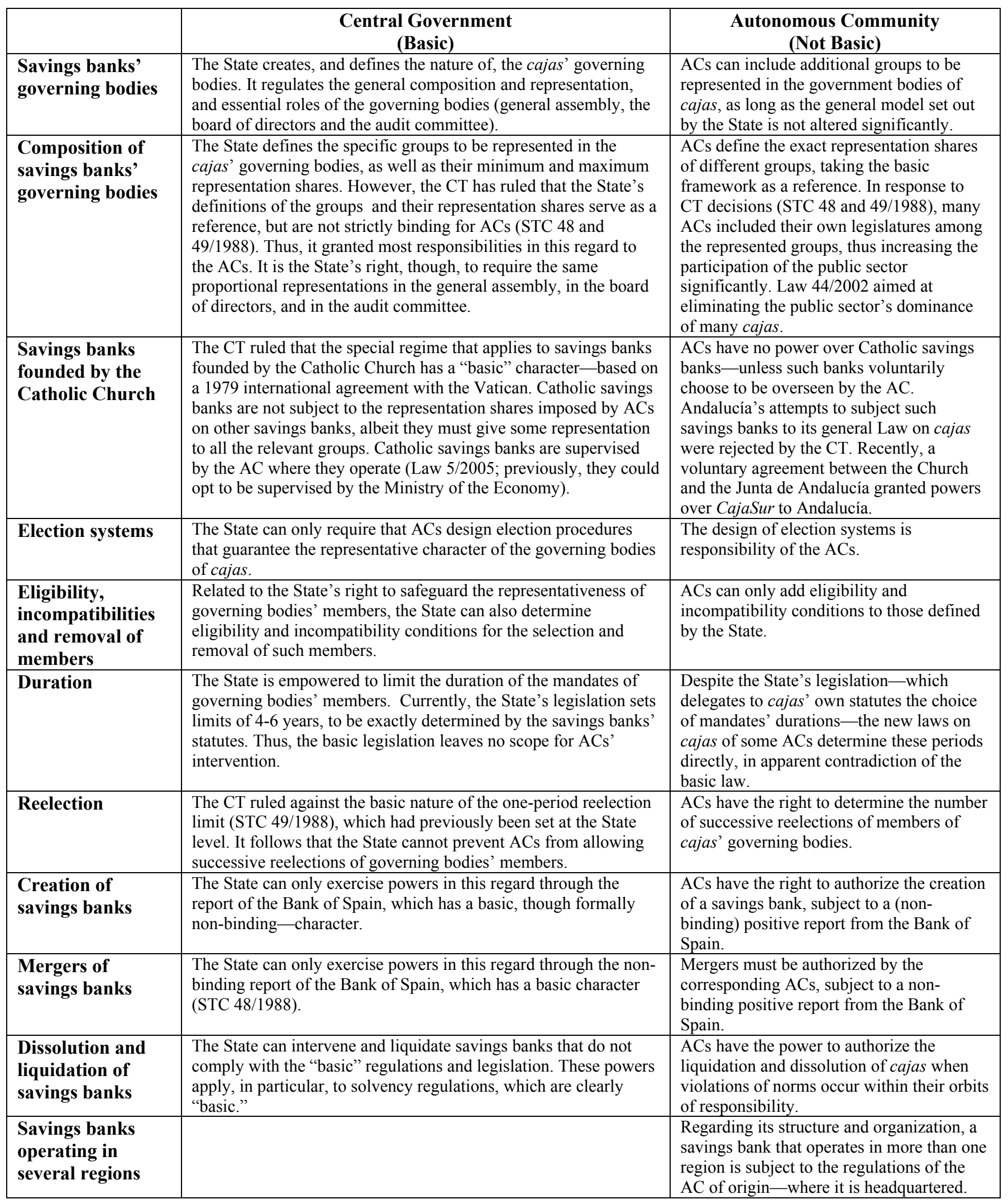


Table 2. Division of Oversight Responsibilities: Cajas Activities

\begin{tabular}{|c|c|c|}
\hline & $\begin{array}{l}\text { Central Government } \\
\text { (Basic) }\end{array}$ & $\begin{array}{c}\text { Autonomous Community } \\
\text { (Not Basic) }\end{array}$ \\
\hline $\begin{array}{l}\text { Distribution of } \\
\text { profits }\end{array}$ & $\begin{array}{l}\text { The Bank of Spain is entitled to prevent the distribution of profits } \\
\text { when the own funds of the savings bank are below } 80 \text { percent of } \\
\text { the minimum own-funds requirement. Also, the Bank of Spain can } \\
\text { authorize an allocation of less than } 50 \text { percent of a caja's profits to } \\
\text { reserves if the caja's own funds exceed by more than } 33 \text { percent } \\
\text { the minimum requirement. } \\
\text { The Ministry of the Economy can authorize-upon request from } \\
\text { the Bank of Spain-a reduction in the allocation of profits to } \\
\text { reserves to avoid the interruption of obras sociales. The Ministry } \\
\text { of the Economy is also empowered to authorize the distribution of } \\
\text { profits and the obra social of savings banks founded by the } \\
\text { Catholic Church. }\end{array}$ & $\begin{array}{l}\text { In all other circumstances, ACs are } \\
\text { empowered-and indeed have complete } \\
\text { discretion in some cases-to authorize the } \\
\text { distribution and use of profits. }\end{array}$ \\
\hline $\begin{array}{l}\text { Discipline and } \\
\text { sanctioning }\end{array}$ & $\begin{array}{l}\text { The State is empowered to apply its discipline mechanisms and } \\
\text { sanctioning powers when savings banks violate "basic" norms. } \\
\text { This applies, in particular, to norms related to solvency and } \\
\text { stability, monetary and financial policy. The violations and } \\
\text { sanctions defined in the Law of Discipline and Intervention of } \\
\text { Credit Institutions apply with equal force to banks and cajas. The } \\
\text { European Central Bank is empowered to impose sanctions when a } \\
\text { savings bank violates the reserve requirements. }\end{array}$ & $\begin{array}{l}\text { The ACs can discipline and sanction } \\
\text { savings banks that violate norms in areas of } \\
\text { responsibility attributed to ACs. }\end{array}$ \\
\hline Supervision & $\begin{array}{l}\text { The Bank of Spain and the ACs are empowered to supervise and } \\
\text { inspect savings banks. The ACs must share with the Bank of Spain } \\
\text { the information obtained through their supervisory activities. Also, } \\
\text { the Bank of Spain and ACs can cooperate in supervision through } \\
\text { formal agreements. }\end{array}$ & $\begin{array}{l}\text { The ACs have supervision powers along } \\
\text { with the Bank of Spain. }\end{array}$ \\
\hline $\begin{array}{l}\text { Savings banks } \\
\text { operating in } \\
\text { several regions }\end{array}$ & $\begin{array}{l}\text { The CT has acknowledged that conflicts could arise among ACs } \\
\text { that jointly regulate and supervise savings banks operating in their } \\
\text { regions. Therefore, it empowers the State to enact basic legislation } \\
\text { to resolve such conflicts and regulate the relations among ACs in } \\
\text { these regards. }\end{array}$ & $\begin{array}{l}\text { Regarding its activities, a savings bank } \\
\text { operating in more than one region is subject } \\
\text { to the regulations of all the ACs in which it } \\
\text { operates-territorial criterion. This applies, } \\
\text { for instance, to the allocation of the savings } \\
\text { bank's obra social across regions. }\end{array}$ \\
\hline
\end{tabular}

26. Table 3 illustrates the regulatory and supervisory powers of some large ACs (Madrid, Valencia, País Vasco and Cataluña) over cajas, summarizing the norms set out in their respective savings banks laws on licensing, regulation, supervision and transparency, and sanctioning. It shows that ACs have a significant role in safeguarding transparency and consumer protection, and in authorizing the allocation of profits. In addition, they hold veto powers over merger proposals, and powers to impose authorization requirements for equity investments (Madrid, País Vasco, Cataluña) and lending (País Vasco, Cataluña). Also, the lack of independence of ACs' supervisors from the ACs' executive governments - and possibly from the supervised cajas - appears as a weakness in the current institutional framework. Finally, the constraints imposed on the compensation of members of governing bodies may limit the capacity of cajas to use compensation as an incentive device.

27. The ACs' powers to prevent mergers of cajas across Spain's regions raises concerns about the scope for further consolidation since consolidation has already drastically shrunk the number of cajas headquartered in any industrial AC (Table 4). Thus, they raise the question whether those powers will constrain the ability of the cajas to adapt to the long-term challenges posed by the ongoing integration of European banking. 


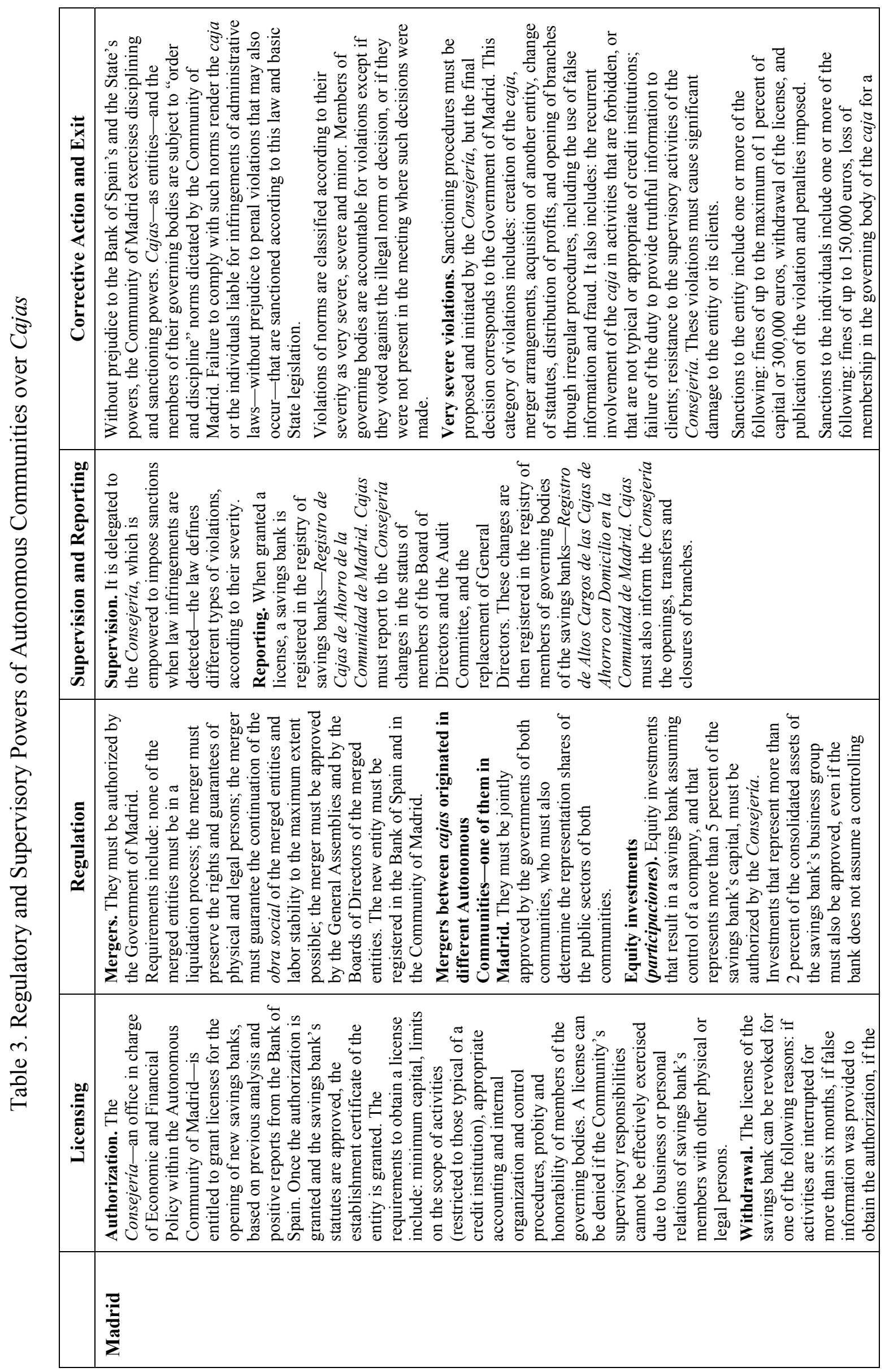




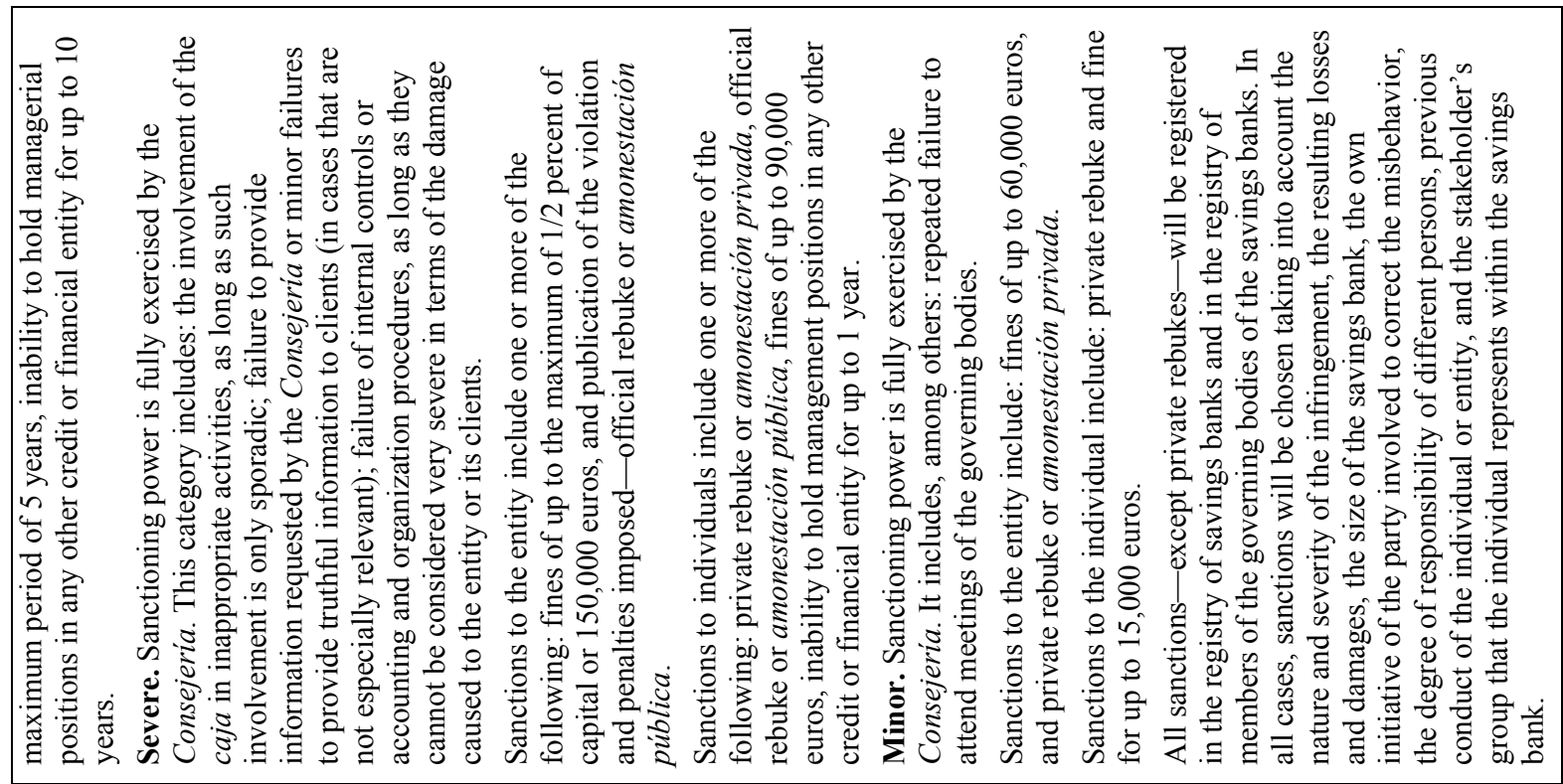

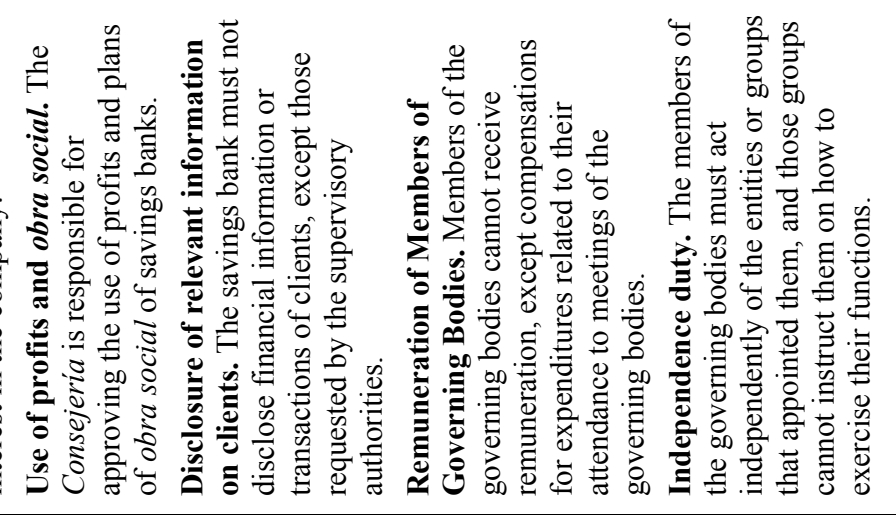

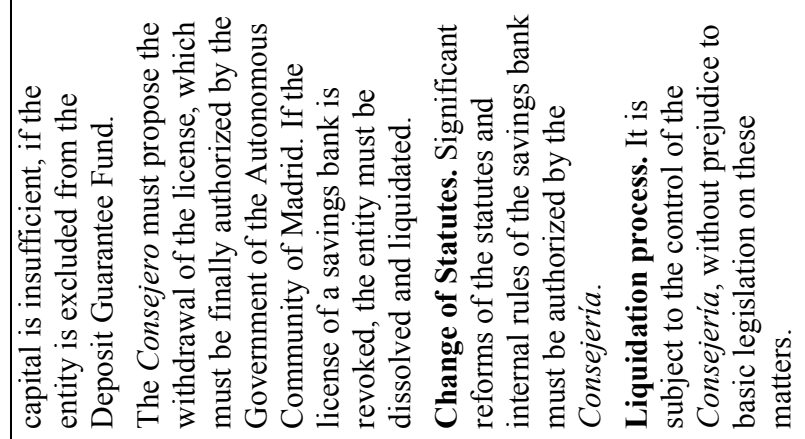




\begin{tabular}{|c|c|}
\hline 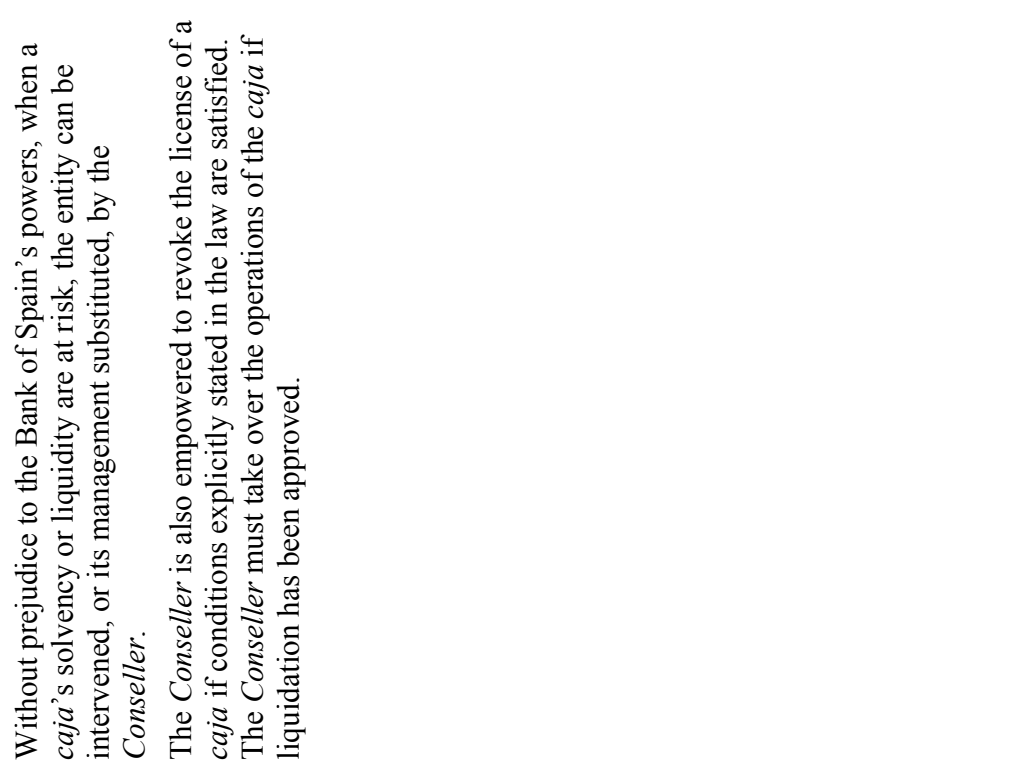 & 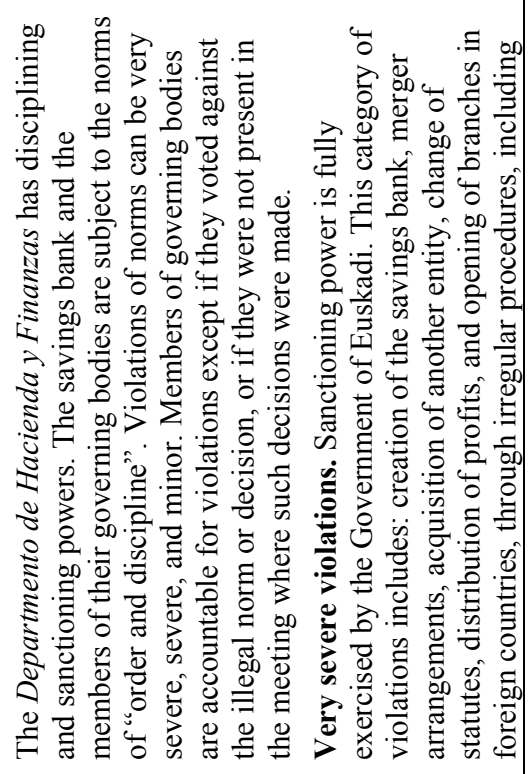 \\
\hline 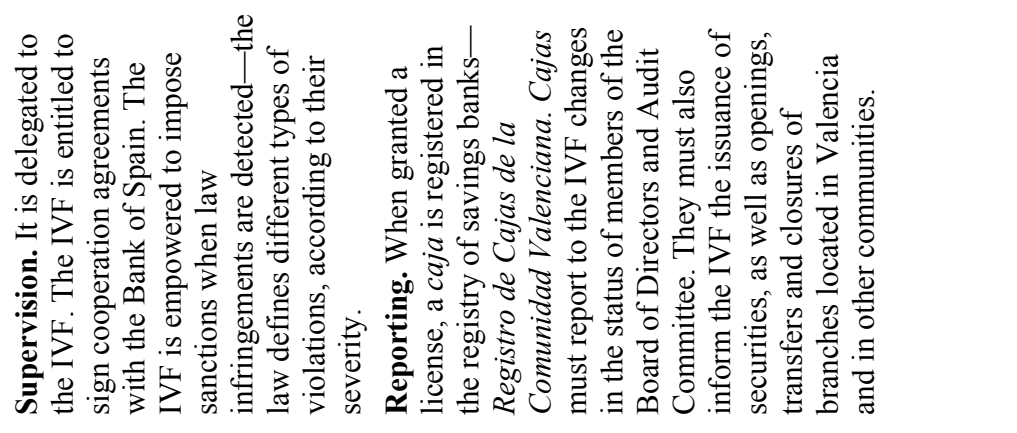 & 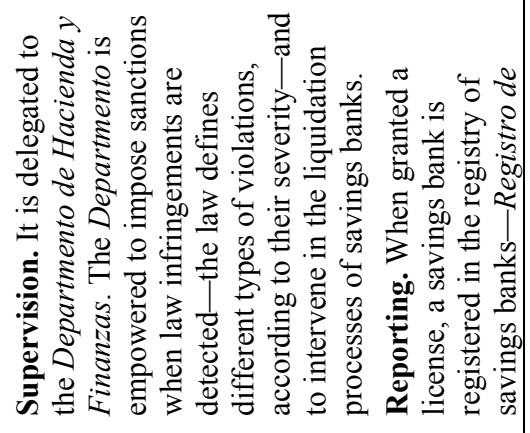 \\
\hline 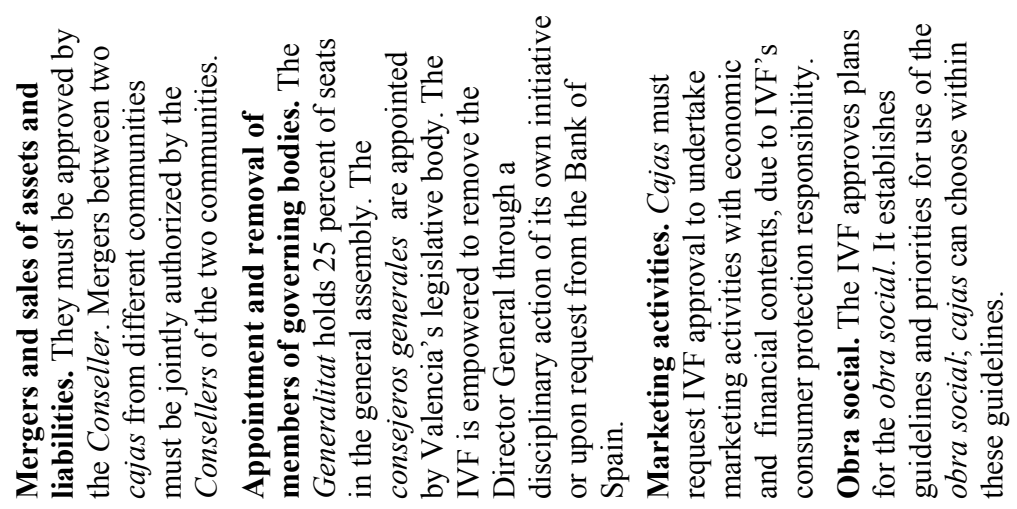 & 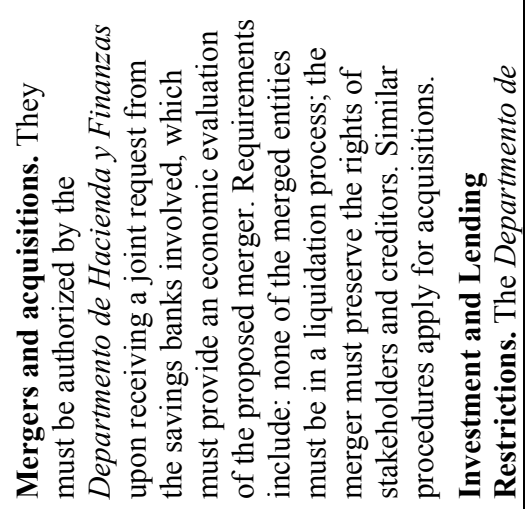 \\
\hline 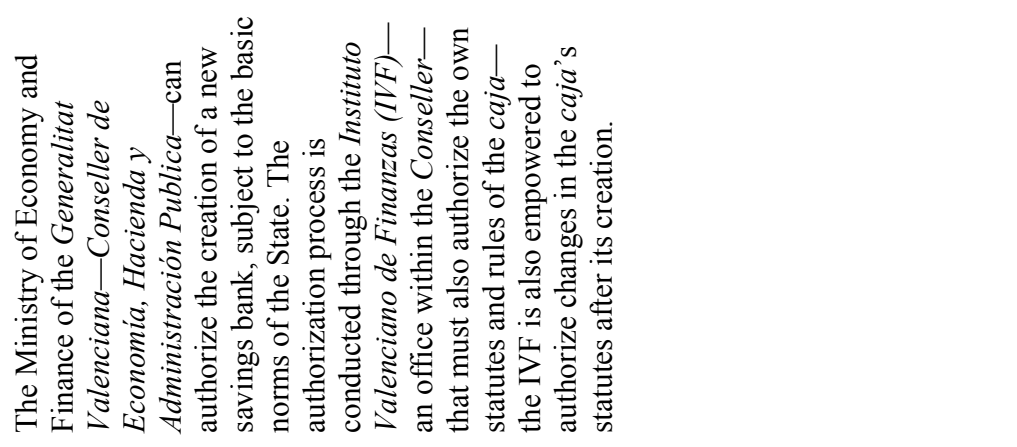 & 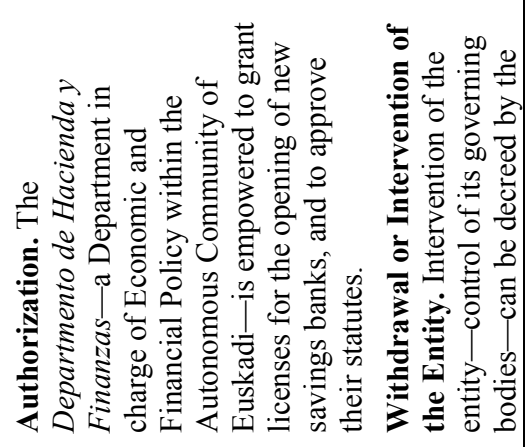 \\
\hline 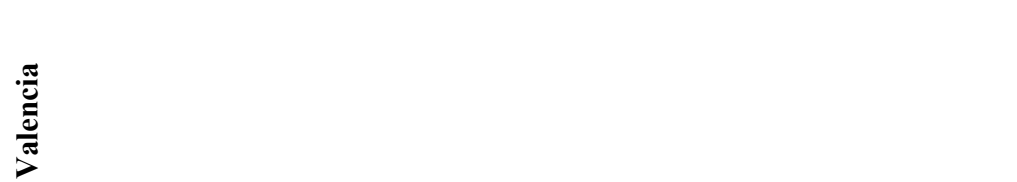 & 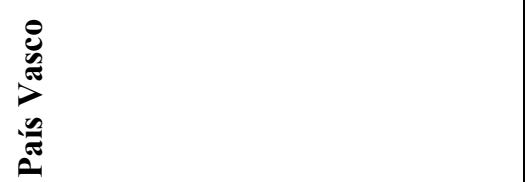 \\
\hline
\end{tabular}




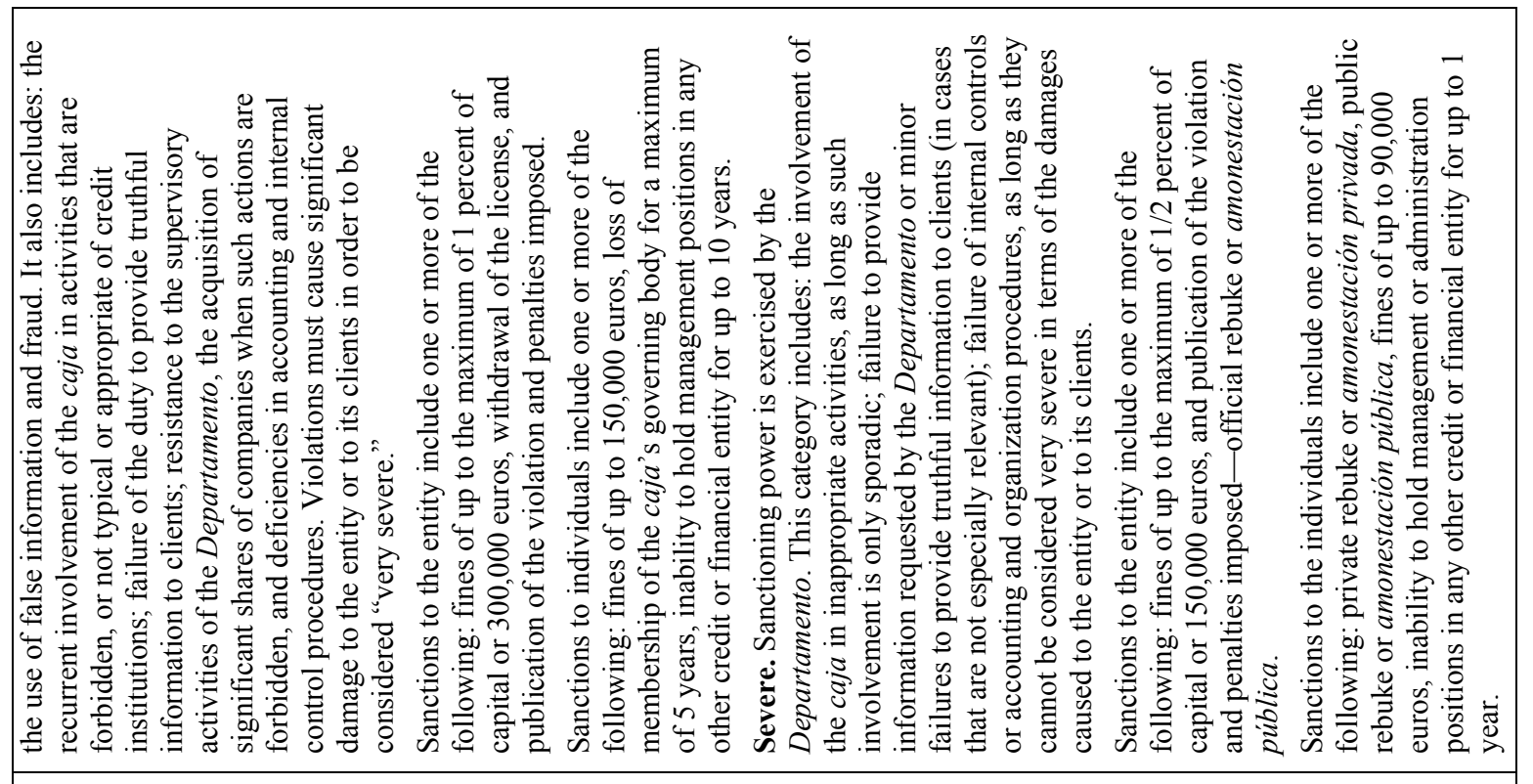

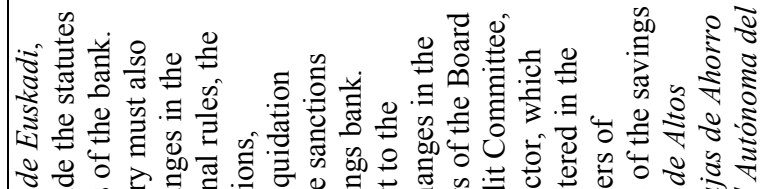

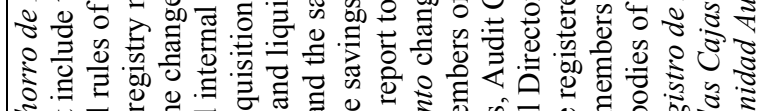

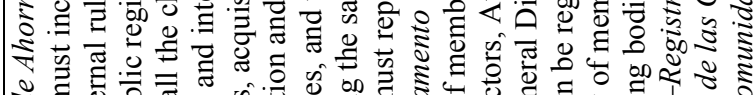

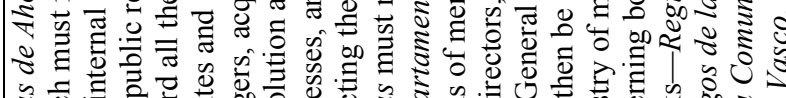

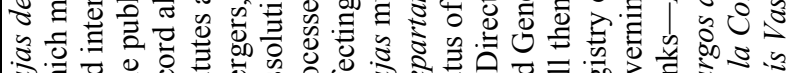

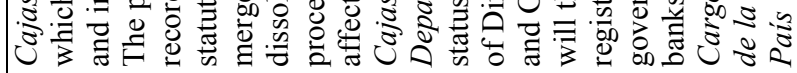

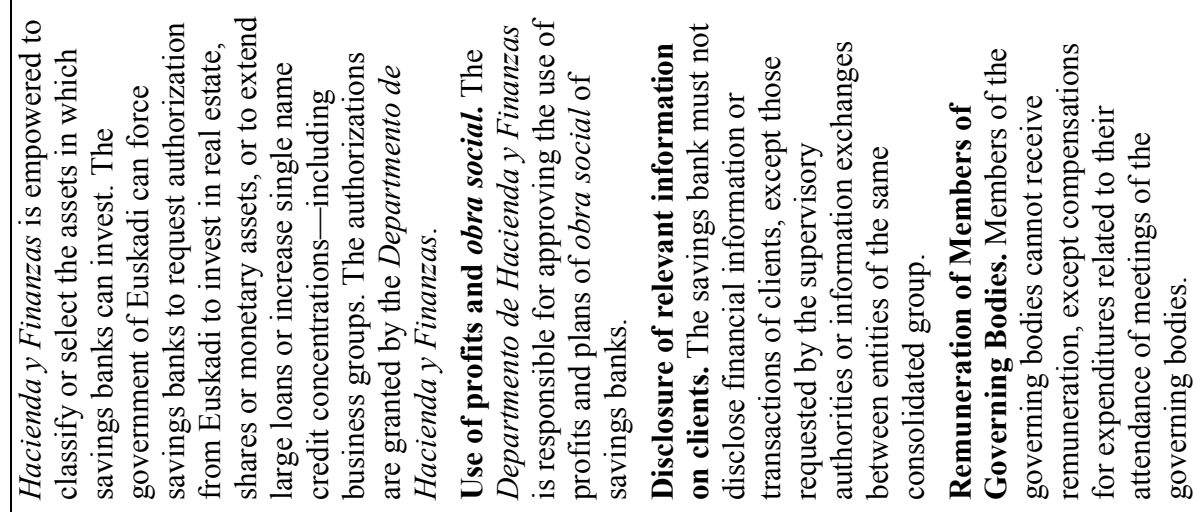

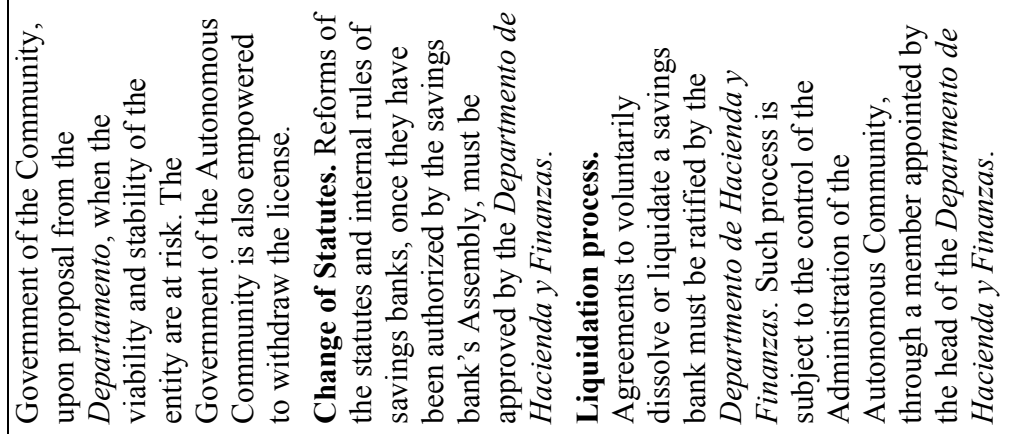




\begin{tabular}{|c|c|}
\hline \multirow[t]{5}{*}{ 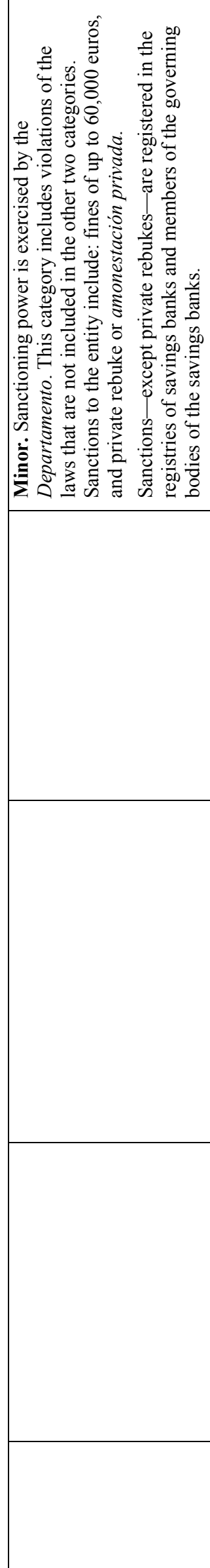 } & 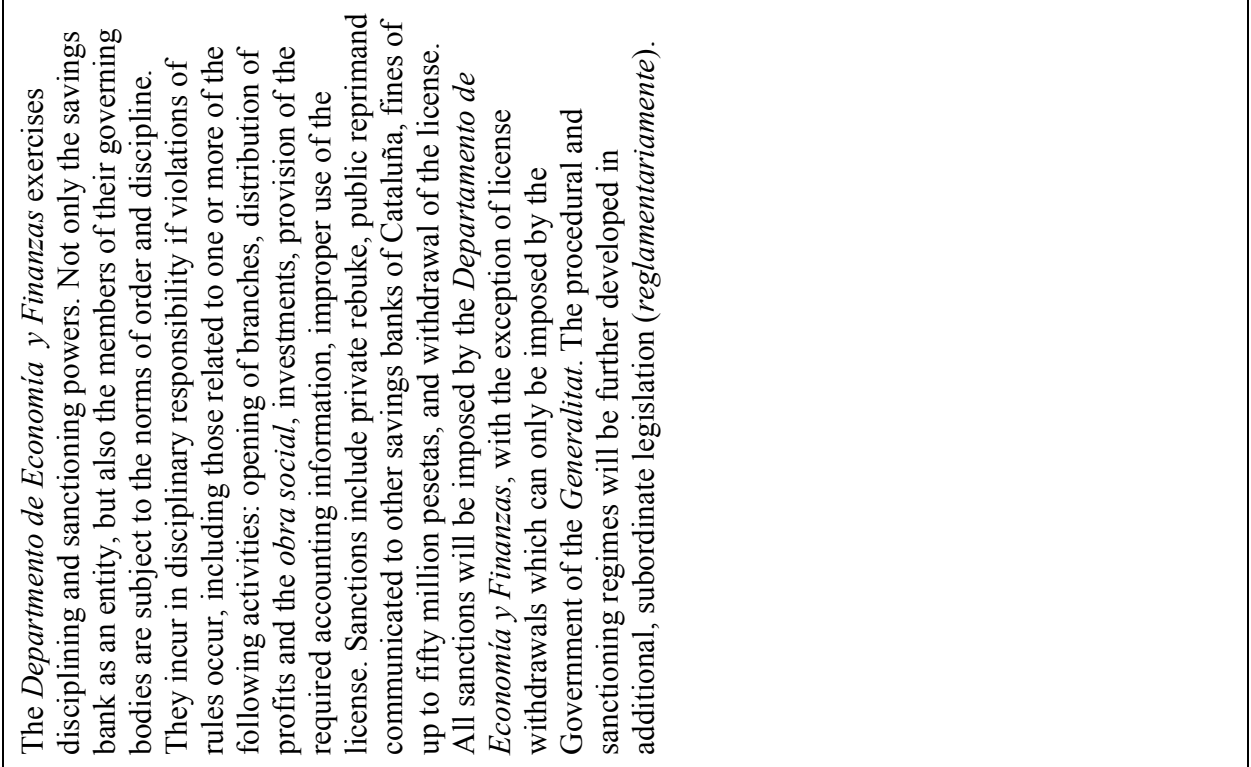 \\
\hline & 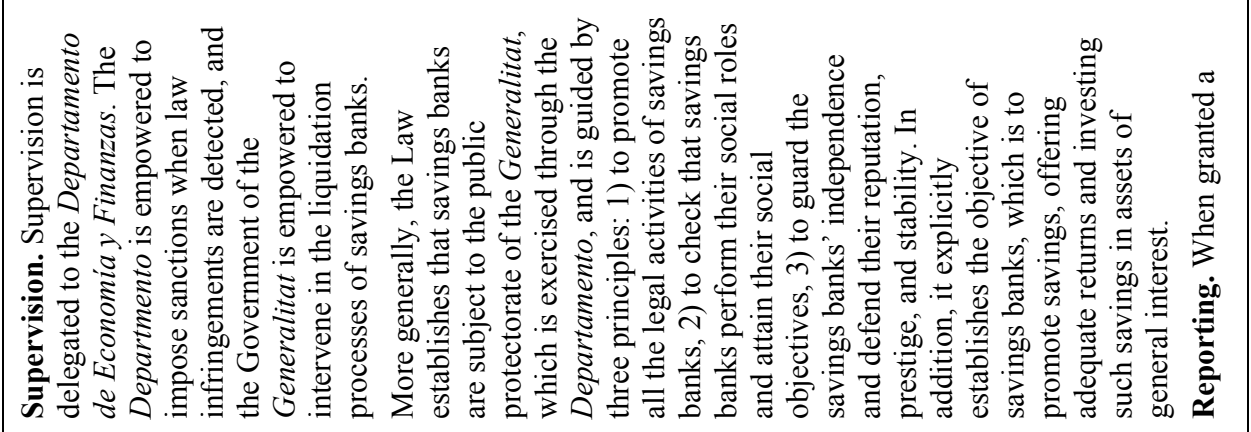 \\
\hline & 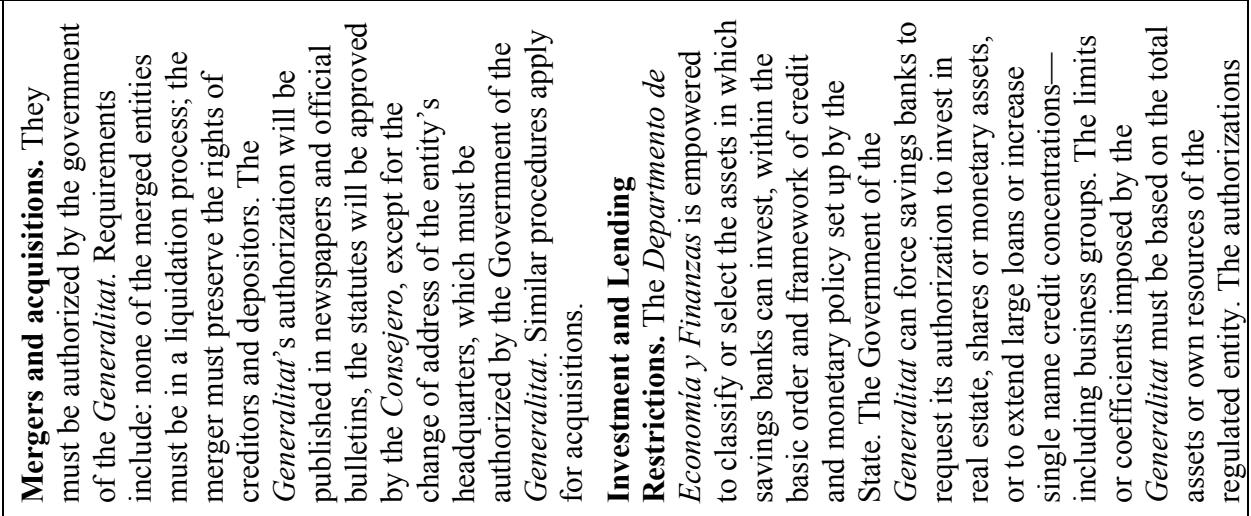 \\
\hline & 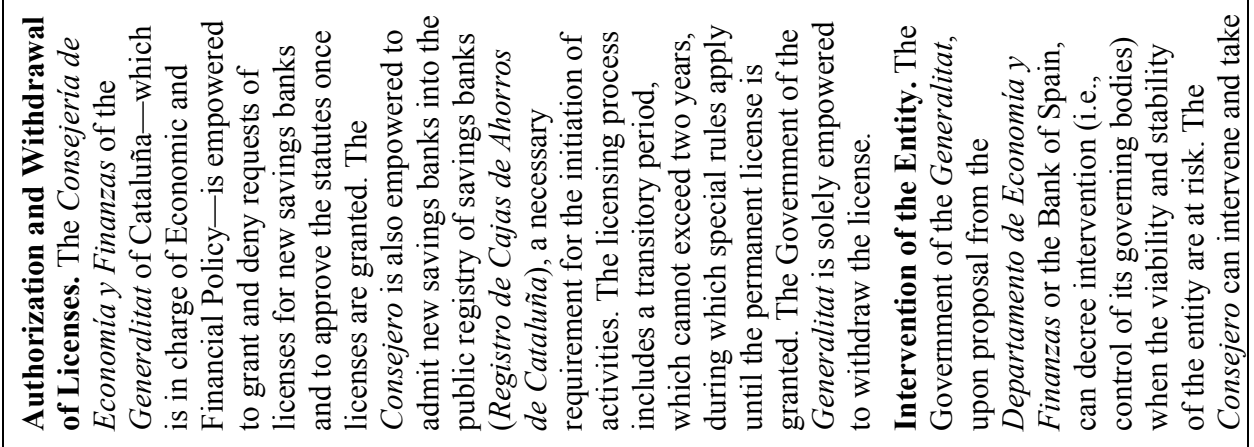 \\
\hline & \\
\hline
\end{tabular}




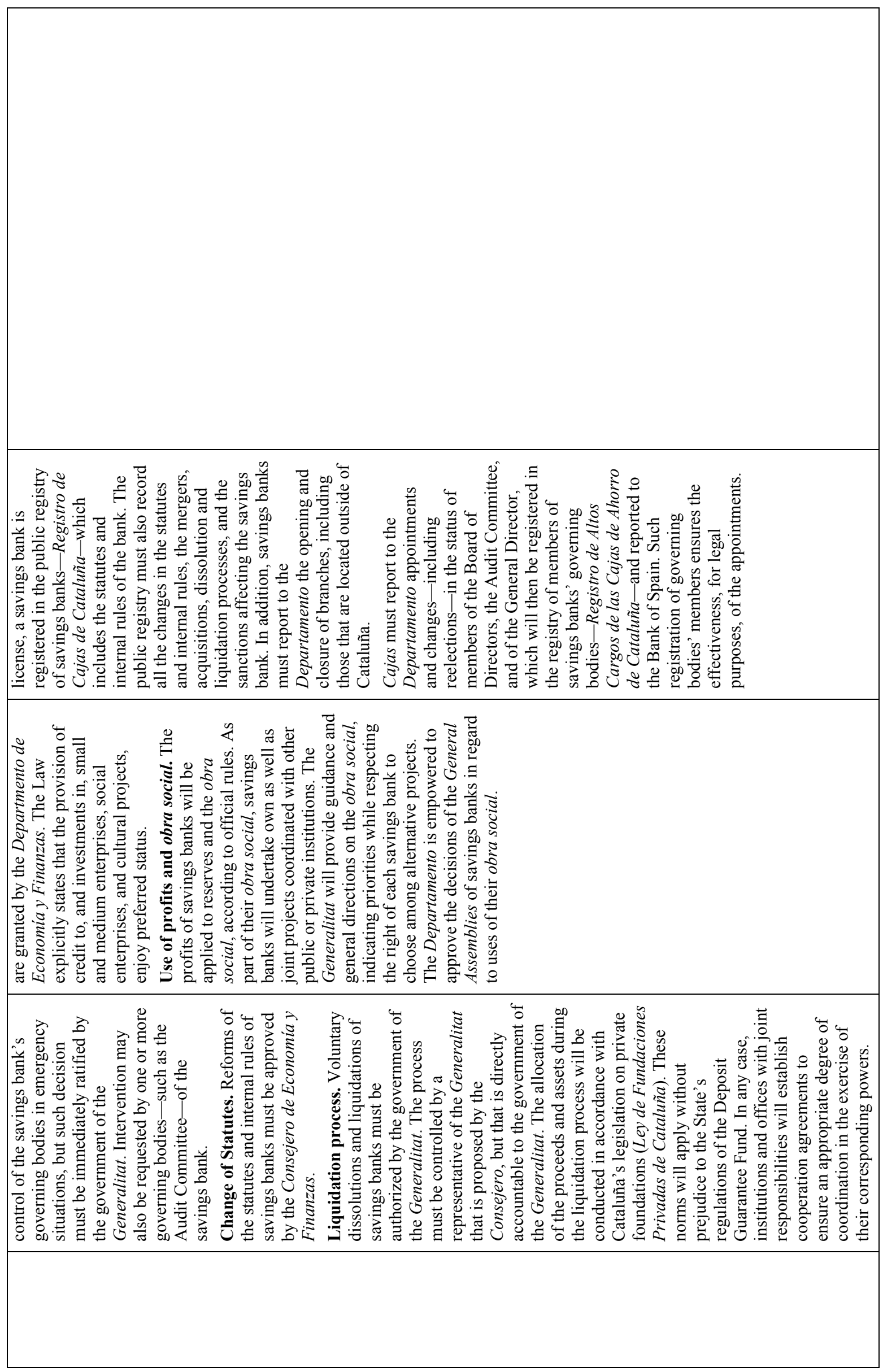


Table 4. Number of Cajas per Autonomous Region

\begin{tabular}{lrrr}
\hline & 1988 & 2003 & Difference \\
\hline Andalucía & 14 & 6 & -8 \\
Aragón & 2 & 2 & 0 \\
Asturias & 1 & 1 & 0 \\
Baleares & 2 & 2 & 0 \\
Canarias & 2 & 2 & 0 \\
Cantabria & 1 & 1 & 0 \\
Castilla y León & 11 & 6 & -5 \\
Castilla-La Mancha & 4 & 2 & -2 \\
Cataluña & 11 & 10 & -1 \\
Extremadura & 4 & 2 & -2 \\
Galicia & 4 & 2 & -2 \\
Madrid & 1 & 1 & 0 \\
Murcia & 1 & 1 & 0 \\
Navarra & 2 & 1 & -1 \\
País Vasco & 6 & 3 & -3 \\
La Rioja & 1 & 1 & 0 \\
C. Valenciana & 9 & 3 & -6 \\
Ceuta y Melilla & 1 & 0 & -1 \\
Total & 77 & 46 & -31 \\
\hline
\end{tabular}

Source: Economistas, No. 98, September 2003.

\section{OTHER ISSUES AND CHALLENGES}

28. This section analyzes the issues raised by public representation, and the challenge of immunizing savings banks from political influence. Also, it identifies barriers that limit the cajas' capacity to raise capital from outside sources, the limits to the market contestability of cajas' performance, and the restrictions on the compensation of members of cajas' governing bodies.

\section{A. Public Representation and Political Influence}

29. In Spain, as in other countries, the substantial representation of the public sector in savings banks' governing bodies raises concerns about the scope for, and the effects of, political influence. ${ }^{20}$

\footnotetext{
${ }^{20}$ It has been argued elsewhere that despite the existing checks and balances, the public sector-and thus political parties - remain highly influential in cajas' governing bodies. See, for instance, Deutsche Bank Research, 2004, "Spain's Cajas: Deregulated, but not Depoliticized," EU Monitor. Financial Market Special, No. 20, December.
} 
30. Historically, the evolution of the public representation and the political influence in the Spanish savings banks' sector has not been linear. The pre-constitutional period was clearly characterized by significant public intervention and political influence. As noted earlier, the liberalization process started in 1977 reduced public sector participation, giving broader representation to different social groups. The LORCA law and CT rulings (STC 48 and 49/1988), gave greater leeway and discretion to local governments to increase their representation shares - particularly municipalities - and caused a temporary setback in the disengagement of the public sector until the Law 44-Ley Financiera - of 2002 was passed.

31. Since the Ley Financiera, Spain has made significant progress in reducing the public sector representation in cajas, and thus, the scope for political influence. ${ }^{21}$ In particular, the representation ceiling of the public sector was reduced to 50 percent, and the irrevocability of the consejeros was institutionalized. These reforms responded to the need of ensuring that cajas' loans and investments would not be considered public aid under European Commission (EC)'s regulations. ${ }^{22}$ In sum, these reforms point to further disengagement of the public sector from savings banks but it is still early to decide whether they will succeed in reducing public sector's influence.

32. The first institutional change - the reduction of the public sector's representation ceiling to 50 percent — may not have fully dissipated perceptions that there may be other channels for political influence. $^{23}$

33. The second institutional change - the "irrevocability" of public sector representatives in the governing bodies of cajas - has helped in creating an armor against political influence, although the fact that members can be reelected still can affect their independence. Although the effectiveness of this mechanism will be tested over the years through successive electoral cycles, it is a significant step toward reducing political influence while preserving public representation. The evidence on comparative turnover of high officials of commercial banks and cajas is mixed. While cajas had a somewhat higher turnover of directors and presidents, they had a much lower turnover of general directors (Table 5). ${ }^{24}$

\footnotetext{
${ }^{21}$ A mitigating factor regarding political influence is that public sector representatives are often from different parties, reflecting the political makeup of the government bodies they represent.

${ }^{22}$ Under EC norms, the definition of public aid applies to the subsidies, loans and investments granted in lax terms (compared with market conditions). The case for public support of enterprises can be more convincingly made when the public sector representation is greater than 50 percent.

${ }^{23}$ For instance, representatives in the assembly of other interest groups — such as "impositores," depositors and workers - may be linked to political parties.

${ }^{24}$ Press coverage suggests that the political parties still argue over high-level appointments at cajas. See, for instance, El Mundo, March 20, 2004, "El PP acepta el regreso del PSOE en la comisión ejecutiva de Caja Madrid;" Expansión, May 20, 2005, "Mas considera 'muy grave' el nombramiento de Sierra al frente de Caixa Cataluña."
} 
Table 5. Executive Turnover in Banks and Cajas, 1986-2000

(In percent per year unless otherwise stated)

\begin{tabular}{lcc}
\hline & Commercial Banks & Cajas \\
\hline Observations (institution/year) & 1246 & 859 \\
& & \\
Turnover of directors & 18.8 & 20.7 \\
Permanence of directors (years) & 5.3 & 4.8 \\
Turnover of presidents & 13.2 & 16.4 \\
Permanence of president (years) & 7.6 & 6.1 \\
Turnover of general director & 31.2 & 13.1 \\
Permanence of general director (years) & 3.2 & 7.6 \\
\hline
\end{tabular}

Source: Presente y futuro de las cajas de ahorros. Fundación CaixaGalicia, 2003.

\section{B. Barriers to the Raising of Capital and Performance Incentives}

\section{Limits to savings banks' capacity to raise capital}

34. Cajas' legal form, which precludes shares issuance, limits their capacity to tap external sources of capital, and they must rely largely on retained profits. Over the past ten years, the cajas channeled over 70 percent of after-tax profits into their revenue reserve every year. Since 1985, however, savings banks can raise capital by issuing subordinated debt (Tier 2 capital) and preferred participations - which are considered part of Tier 1 capital (qualifying preferred participations) or Tier 2 capital (non-qualifying preferred participations).

35. The cajas' limitations in raising equity capital have several implications: (i) they may reduce the scope of these institutions to expand if a particular operation (e.g., a purchase of another institution) requires more capital than what the caja has; (ii) they seriously limit the capacity to replenish capital if for any reason a caja suffers major losses; and (iii) they deprive cajas of an instrument (the value of a share) to assess the market's view on an institution's performance on a continuous basis.

36. To help address those limitations, since 1990 cajas can also raise funds through equity units (cuotas participativas), which are considered part of Tier 1 capital (see Box 1). Nevertheless, cuotas participativas are not standard equity instruments, as they grant no voting rights to holders and their issuance is, in general, more heavily regulated than that of corporate stocks.

37. Moreover, while cuotas participativas can help to address (i) and (iii) above, they are much less useful to deal with a situation of financial distress, where a large and prompt capital injection is needed. In such cases, the voting rights associated with standard equity are crucial to take decisions such as replacing management or restructuring operations, and thus facilitate capital infusions. 
38. By end-2005 no cuotas participativas had been issued, partly because cajas had ample capital and partly because they had access to alternative, cheaper, sources of capital. ${ }^{25}$ In particular, preferred participations (participaciones preferentes) had been used intensively by some cajas during 1999-2001, but their share in regulatory capital was capped to 30 percent in $2003 .^{26}$

39. Some features of the cuotas participativas - besides their lack of voting power - that might entail some uncertainty for potential issuers and investors are the following.

- $\quad$ First, although the cuota is a variable-income instrument, the legal framework allows cajas to smooth the returns earned by the cuota-holders (cuota-participes) through a dividend stabilization fund. Such a smoothing mechanism diminishes the variable income nature of the instrument and may have added uncertainties.

- $\quad$ Second, the cajas' discretion to allocate profits to the obra social could give rise to concerns about dilutions of the cuota-holders' shares in the profits of the caja. However, such dilution, if it occurs, is of limited practical concern because there are no voting rights attached to the cuota-holders' shares. ${ }^{27}$

- $\quad$ Third, there is a widespread belief in a "first-mover-disadvantage" among potential issuers that could delay the issuance of the cuotas to the market. The instrument's specificities imply that the first issuer will incur some transaction costs - associated, for example, with advertising the investors' rights through the CNMV-which later issuers will largely avoid. In addition, initial offerings of cuotas may be subject to investors' aversion toward new instruments, but such uncertainties are likely to fade over time as they learn that the instrument is accepted and actively traded.

40. Box 2 describes the successful reform experience of Norway's savings banks that introduced capital instruments that grant voting rights to investors but that are otherwise similar to cuotas participativas.

\footnotetext{
${ }^{25}$ The General Assemblies of some cajas, such as Caixa Galicia, have authorized the issuance of cuotas participativas, but they have not been effectively issued. CECA has issued cuotas participativas that were purchased by its members (individual cajas). Before the reform in the legal framework of cuotas participativas, which started with the Ley Financiera of 2002, the cajas had been reluctant to issue them because the law was unclear as to the influence investors could exercise through them.

${ }^{26}$ Law 19/2003 of July 4, 2003, states that the outstanding amount of participaciones preferentes cannot be greater than 30 percent of Tier 1 capital, without prejudice to restrictions that the Bank of Spain may impose on the use of participaciones preferentes for regulatory capital purposes. Both preferred participations and subordinated debt are used more intensively by cajas than by banks, precisely because of the cajas' restrictions to issue shares.

${ }^{27}$ Furthermore, Royal Decree 302/2004 allows cajas to undertake corrective actions to avoid such dilutions of cuota-holders' in profits.
} 


\section{Box 1. Capital Instruments Available to Spanish Savings Banks: Cuotas Participativas and Participaciones Preferentes}

The capital instruments available to savings banks are the cuotas participativas (Tier 1), the participación preferente (Tier 1 in the case of qualifying preferred participations and Tier 2 in the case of non-qualifying preferred participations), and subordinated debt (Tier 2). The Spanish legal framework requires both cuotas participativas and participación preferente to be issued as securities that are publicly traded in exchanges, whereas subordinated debt may or may not be publicly traded. Preferred shares and subordinated debt can be issued by all financial institutions, while cuotas participativas are specific for cajas.

\section{Cuotas Participativas}

A cuota participativa is an equity-like variable income instrument that grants no voting rights to its holder. The instrument was introduced in the Spanish legislation in 1990 (Decree 664). The Ley Financiera of 2002 and the Decree 302 of 2004 modified the previous legal framework.

Holders of cuotas participativas have economic rights such as the participation in profits through variable dividends - the base to compute the minimum allocation of the profits to the obra social excludes that part of the profits that corresponds to cuota-holders. In case of liquidation of the entity, the holder has the right to receive its share of the liquidation value. In case of premature amortization of the cuota, the holder has the right to receive its market value. Although the legislation included a clause that grants investors a preferential subscription right over new cuotas, it has been recently ruled out by a decision of the Constitutional Tribunal - in a suit filed by a labor union (Comisiones Obreras).

The issuance of cuotas, as well as the distribution of annual dividends must be approved by the General Assembly of the caja, which can delegate the operational issuance decisions - such as the timing and the exact amounts - to the Board of Directors.

The General Assembly can also approve the creation of a group of cuota-holders to which the representation of all cuotaholders will be delegated. This group will have the right to participate in the General Assembly with voice but with no voting power.

The legal framework establishes some limits to the amounts issued by a savings bank and to cuota-holdings by individuals, as follows: the volume of cuotas issued cannot exceed 50 percent of the entity's net worth, and no natural or legal person can acquire more than 5 percent of cuotas issued.

\section{Participaciones Preferentes}

In Spain, a preferred participation or participación preferente is a subordinated debt instrument that grants the holder the right to receive a fixed dividend when the issuer (a caja) obtains profits, and no right to dividends when the institution suffers losses. The legal framework for the issuance of participaciones preferentes in Spain was approved in 2003.

Before 2003, many savings banks relied heavily on the issuance of participaciones preferentes abroad to finance their operations. ${ }^{1}$ The savings banks were unable to issue the participaciones preferentes in Spain because an appropriate legal framework was lacking - particularly regarding their ability to absorb losses. In particular, the legal nature of savings banks precludes them from issuing securities granting ownership and voting rights in the cajas - but private ownership rights could be established over the special vehicles controlled by the cajas. The legal framework established in 2003 adapted the participaciones preferentes to the Spanish legislation by treating them like bonds, making it possible to issue them in Spain.

${ }^{1}$ They issued the participaciones preferentes through special purpose vehicles located in offshore centers with Anglo-Saxon legislation. The instrument granted voting rights to the holders; those rights were limited to the vehicle itself but excluded the caja. 


\section{Box 2. Savings Banks and Capital Instruments in Norway}

Norway's reform of the savings banks system introduced financial instruments, the so-called primary capital certificates (PCCs), which are broadly similar to the "cuotas participativas," but provide voting rights to their holders and are tradable. Such instruments have proved to be an effective vehicle to capitalize the savings banks - they accounted for 16.1 percent of savings banks capital (including subordinated debt) in 2000. They have been used mainly by the large savings banks.

Characteristics of primary capital certificates (PCCs):

- Property and dividend rights. The certificates confer property rights over the capital and profits of the savings bank. The latter can be distributed as dividends or accumulated in a dividend stabilization fund. In case of liquidation of the savings banks, PCC holders have the right to receive their share of capital and the dividend stabilization fund, after all creditors' claims have been fully repaid.

- Voting rights. PCC's voting rights are not proportional to their share of capital, which makes such certificates different from equity. PCC holders choose one quarter of the members of the general assembly, whereas the other interest groups (depositors, employees, and public sector representatives) choose the remaining three quarters. A proposal to increase PCC holders' representation to 40 percent is under analysis.

- Other. Savings banks can issue securities convertible into PCCs, which has expanded their financing options. In order to issue PCCs, a qualified majority vote of two thirds of the general assembly is necessary. In addition, the ownership of PCCs is unrestricted, with the only exception that no individual or legal person can hold more than 10 percent of the PCCs of a single savings bank.

41. Cajas have not suffered systemic crises. As noted earlier, individual distress cases were resolved through mergers among cajas. Assuming that in a distress situation instruments such as cuotas participativas would not be very helpful, the remedies available to deal with the situation (besides mergers) would include sale of assets or support from the deposit guarantee fund. Thus, it is even more important for cajas than banks to have a solid equity position that provides a cushion in case of losses, and to maintain a risk profile that takes fully into account the difficulties in promptly bringing in substantial amounts of new capital. In practice, cajas as a group have higher capitalization.

\section{Limited market assessment and contestability of cajas' performance}

42. The assessment and contestability of cajas' performance by markets are more limited than those of commercial banks in two dimensions. First, lacking owners, cajas cannot be purchased by private parties, and standard ownership rights - such as voting - do not apply. Second, cajas' do not issue tradable equity instruments which would allow their day-to-day decisions to be fully assessed by capital market participants.

43. In regard to the first dimension of contestability - through takeovers - cajas cannot be purchased by private individuals or institutions due to their legal nature, but they can acquire other companies and credit institutions. Nevertheless, cajas' assets and branches can 
be purchased by individuals, private companies and commercial banks. Mergers and acquisitions among cajas, however, are possible so long as the Autonomous Communities give their approval (see Section IV).

44. In regard to the second dimension - the contestability of cajas' day-to-day decisions - the fact that cajas, unlike many banks, are not listed companies, implies that the market assessment of managers' decisions is more limited. Such assessment would not be continuously reflected in equity price signals in capital markets. ${ }^{28}$ Although cajas issue debt instruments, the value of these instruments reflect the cajas' market value only to a limited degree.

45. Transparency is a key element to facilitate good governance of any organization, and is particularly important for the cajas. The transparency of cajas' decisions is set to improve significantly. Starting in 2005, cajas that issue traded instruments must publish an annual Governance Report, which will enhance transparency and market oversight.

46. In addition, a working group led by the CNMV has opened a consultation and study period to propose further improvements to the corporate governance of publicly traded firms and savings banks. A special subgroup is focused on the governance of savings banks to determine which of the general proposals could be applied to savings banks - given their specific legal nature. One of the proposals considered so far is the creation of a Corporate Governance Code that unifies all previous corporate governance recommendations and the current legislation - contained in laws, ministerial orders, circulars and other sets of recommendations such as the Aldama and Olivencia Codes. A first draft has been released for comments, albeit specific recommendations for savings banks will be released later. ${ }^{29}$

\section{Compensation of members of cajas' governing bodies}

47. Unlike commercial banks, cajas cannot make use of stock options to compensate their executives - due to the absence of stock prices for cajas - and thus, are deprived of a potentially useful device to induce profit maximization. However, this may also discourage excessive risk-taking, as the use of stock options to compensate executives has led to excessive risk-taking and corporate failures in other countries. ${ }^{30}$ Savings banks, however, appear to have no difficulties to attract the best professionals, as executives receive compensation appropriate to market conditions. ${ }^{31}$

\footnotetext{
${ }^{28}$ FitchRatings, 2005, The Framework for Corporate Governance in Major European Banking Systems. Still Evolving, but Good Progress Made, Special Report, April.

${ }^{29}$ The recommendations may also be applicable to the minority of savings banks that do not issue traded securities.

${ }^{30}$ This view is advanced, for example, by the IMF's Director of the Research Department Raghuram Rajan, "Has financial development made the world riskier?" mimeo, September 2005.

${ }^{31}$ As indicated in Table 3, compensation to non-executive members of governing bodies is restricted by law to "dietas por asistencia y desplazamiento"- expenditures related to their attendance of cajas' meetings.
} 


\section{CONCLUSIONS AND RECOMMENDATIONS}

48. The savings banks (cajas) have been a major force in extending services and in creating a highly competitive environment in the Spanish financial system. They have close ties with the communities and they support social, cultural, and educational projects. Cajas have endeavored to keep close to their customer base and have successfully adapted to the liberalization of the Spanish financial sector. They have a large network of branches and a strong regional identity, and since 1980 have steadily increased their market share of customer deposits and total credit to the private sector - which is concentrated in lending to individuals and to small- and medium-size enterprises - to account for more than one-half of the system in 2005. Cajas have built a strong capital base over the years and the system has suffered no systemic crisis.

49. Notwithstanding the overall strengths of the savings banks system, the peculiar structure of savings banks - foundations that do not have owners - requires adequate arrangements that ensure good governance and help them maintain a strong market orientation. In this regard, the following actions would help:

- $\quad$ Ensuring that the 2002 regulations on corporate governance are fully implemented, strengthening them if required in particular as regards outside influence on the savings banks' decisions.

- $\quad$ Promoting new means to raise high-quality capital, such as the issuance of cuotas participativas to the market.

- $\quad$ Allowing savings banks to merge freely within and across Autonomous Communities provided the Bank of Spain has ruled favorably on the viability of the merged institution.

- $\quad$ Reducing over time the public sector representation ceiling, currently at 50 percent.

50. Regarding the division of regulatory and supervisory responsibilities over savings banks, the Autonomous Communities' powers do not include solvency or financial stability issues, in line with rulings by the Tribunal Constitucional handed down over many years. Looking to the future, eventual changes in the legal regime should clearly preserve the sole and exclusive role of the Bank of Spain in prudential oversight - solvency and financial stability issues - of all financial institutions, including savings banks. In this regard, it is particularly important to avoid any possible inconsistency in the division of responsibilities between the Bank of Spain and the Autonomous Communities. This would help ensure that Spanish financial supervision is consistent with the present trend observed in European and international markets towards avoiding fragmentation and enhancing harmonization.

51. Looking forward to the long term, a weakness of the current model is that its resolution mechanisms are basically restricted to mergers or asset sales. Although mergers among cajas could be useful — though not necessarily optimal — to resolve the financial difficulties of smaller cajas, they could not be relied on to resolve systemically important cajas. The incapacity of cajas to raise capital through instruments that grant voting rights 
precludes a potentially useful — less costly — vehicle to resolve cajas with problems - which could be particularly relevant for large cajas. In this regard, the Spanish authorities may wish to consider strengthening the current model by introducing alternative resolution mechanisms. One possibility would be to allow a caja to issue capital instruments with attached voting rights if the caja is in serious distress or its assembly wishes to do so. More broadly, the supervisor needs to remain particularly vigilant in order to ensure that the risk profile of cajas takes fully into account the difficulties of bringing in promptly substantial amounts of new capital. 